\title{
Distillation Time Modifies Essential Oil Yield, Composition, and Antioxidant Capacity of Fennel (Foeniculum vulgare Mill)
}

\author{
Valtcho D. Zheljazkov ${ }^{1 *}$, Thomas Horgan², Tess Astatkie $^{3}$ and Vicki Schlegel ${ }^{4}$ \\ ${ }^{1}$ University of Wyoming, Sheridan Research and Extension Center, 663 Wyarno Road, Sheridan, WY 82801, U.S.A. \\ ${ }^{2}$ Mississippi State University, North Mississippi Research and Extension Center, 5421 Highway 145 South, Verona, MS 38879, U.S.A. \\ ${ }^{3}$ Dalhousie University, Faculty of Agriculture, 50 Pictou Road, P.O.Box 550, Truro, NS B2N 5E3, Canada \\ ${ }^{4}$ University of Nebraska - Lincoln, Department of Food Science and Technology, 327Food Technology Complex, Lincoln, NE 68583, U.S.A.
}

\begin{abstract}
Fennel (Foeniculum vulgare Mill) is an essential oil crop grown worldwide for production of essential oil, as medicinal or as culinary herb. The essential oil is extracted via steam distillation either from the whole aboveground biomass (herb) or from fennel fruits (seed). The hypothesis of this study was that distillation time (DT) can modify fennel oil yield, composition, and antioxidant capacity of the oil. Therefore, the objective of this study was to evaluate the effect of eight DT $(1.25,2.5,5,10,20,40,80$, and $160 \mathrm{~min})$ on fennel herb essential oil. Fennel essential oil yield (content) reached a maximum of $0.68 \%$ at $160 \mathrm{~min}$ DT. The concentration of trans-anethole (32.6-59.4\% range in the oil) was low at $1.25 \mathrm{~min}$ DT, and increased with an increase of the DT. Alpha-phelandrene (0.9-10.5\% range) was the lowest at $1.25 \mathrm{~min}$ DT and higher at 10, 80, and $160 \mathrm{~min}$ DT. Alpha-pinene (7.1-12.4\% range) and beta-pinene (0.95-1.64\% range) were higher in the shortest DT and the lowest at $80 \mathrm{~min}$ DT. Myrcene (0.93-1.95\% range), delta-3-carene (2.1-3.7\% range), cis-ocimene (0-0.23\% range), and gamma-terpinene (0.22-2.67\% range) were the lowest at $1.25 \mathrm{~min}$ DT and the highest at $160 \mathrm{~min}$ DT. In contrast, the concentrations of paracymene $(0.68-5.97 \%$ range), fenchone (9.8-22.7\% range), camphor (0.21-0.51\% range), and cis-anethole (0.14-4.66\% range) were highest at shorter DT (1.25-5 min DT) and the lowest at the longer DT (80-160 min DT). Fennel oils from the 20 and $160 \mathrm{~min}$ DT had higher antioxidant capacity than the fennel oil obtained at $1.25 \mathrm{~min}$ DT. DT can be used to obtain fennel essential oil with differential composition. DT must be reported when reporting essential oil content and composition of fennel essential oil. The results from this study may be used to compare reports in which different DT to extract essential oil from fennel biomass were used.
\end{abstract}

Key words: Aromatic plants, steam distillation, essential oil yield, trans-anethole, alpha-phellandrene, fenchone, alphapinene, paracymene

\section{INTRODUCTION}

Fennel (Foeniculum vulgare Mill) is a major essential oil crop grown for production of essential oil or as herb throughout the world; it is one of the principal essential oil crops in the temperate region ${ }^{1)}$. Current production of fennel essential oil is concentrated in Europe(Bulgaria, France, Germany, Italy, Romania, Hungary, Turkey, Ukraine, Russia, Yugoslavia), in some Asian countries (India, China), in South America (Argentina) and in the United States. Fennel is used as spice (seeds), edible herb (aboveground plant parts or the roots), and as medicinal herb. Fennel has been used as medicinal herb since ancient times, especially in medical systems of various cultures around the Mediterranean region ${ }^{2}$. For example, Bulgarian folk medicine has been utilizing fennel as baby colic remedy, for treating stomach pain, indigestion, as anesthetic, antispasmodic, carminative, for increasing milk supply in nursing mothers ${ }^{2)}$. Fennel oil is also used as an aromatic ingredient in the food, canning, and beverage industries. Indeed, fennel extract has shown some antioxidant properties ${ }^{3,4)}$, and anti-inflammatory properties ${ }^{5)}$.

Commercially, fennel essential oil is obtained via steam distillation of the fresh herbage (all aboveground plant parts harvested and distilled at flowering stage), or from

\footnotetext{
*Correspondence to: Valtcho D. Zheljazkov, University of Wyoming, Sheridan Research and Extension Center, 663 Wyarno Road, Sheridan, WY 82801, U.S.A.

E-mail: vjeliazk@uwyo.edu, or valtcho.pubs@gmail.com

Accepted April 6, 2013 (received for review March 18, 2013)

Journal of Oleo Science ISSN 1345-8957 print / ISSN 1347-3352 online

http://www.jstage.jst.go.jp/browse/jos/ http://mc.manusriptcentral.com/jjocs
} 
fennel seed (fruits). The chemical profile of fennel herb oil and fennel seed oil are different; most of the commercially available fennel oil is produced from fennel herbage.

The length of the distillation time(DT) was found to affect both essential oil yield and oil profile of some other aromatic plants such as Japanese cornmint (Mentha canadensis L. $)^{6)}$, oregano (Origanum vulgare L.) ${ }^{7}$, pine (Pinus ponderosa Dougl. ex Laws ${ }^{8)}$, (Menthax piperita L.), lemongrass (Cymbopogon flexuosus Steud.) and palmarosa (Cymbopogon martinii Roxb.) ${ }^{9}$, of female and of male Rocky Mountain juniper (Juniperus scopulorum Sarg. $)^{10,11)}$, but DT effect for fennel was not reported. We hypothesized that DT can modify fennel oil yield, composition, and antioxidant capacity. If the hypothesis is correct, then perhaps it would be possible to obtain fennel oil with specific composition by modifying the DT. The objective of this study was to evaluate the effect of eight DT $(1.25,2.5$, $5,10,20,40,80$, and $160 \mathrm{~min}$ ) on fennel herb essential oil, and to develop regression models that describe the relationship between DT and essential oil content, and the concentration and yield of its constituents.

\section{MATERIALS AND METHODS}

The fennel used in this study was grown in 2010 at the North Mississippi Research and Extension Center at Verona, MS ( $34^{\circ} 43^{\prime} 22^{\prime \prime} \mathrm{N}$ and $\left.-88^{\circ} 43^{\prime} 22^{\prime \prime} \mathrm{W}\right)$. Certified seeds from Bulgarian fennel cultivar 'Shumen' were used in this study. This cultivar is commercially grown for essential oil production in Bulgaria ${ }^{12)}$. Transplants were started in a greenhouse in January and transplanted out in the field in May 2010. Fennel transplants were transplanted at previously prepared raised beds, with drip tape irrigation tubing at 5-6 cm deep, running in the middle of each bed. Plants were spaced $45 \mathrm{~cm}$ apart and grown under irrigation. Phosphorus and potassium were provided prior to planting based on soil test reports. Nitrogen was applied at $120 \mathrm{~kg} / \mathrm{ha}$. Plants were harvested at flowering, by cutting with a hedge trimmer at 10-12 cm above the soil surface, and processed immediately for essential oil extraction.

\subsection{Steam distillation and distillation times (DT)}

Fresh fennel samples (400 g of above ground herbage, including stems, leaves, umbels with immature seeds), in 3 replicates, were extracted via steam distillation in $2-\mathrm{L}$ steam distillation units as described previously ${ }^{9}$. Briefly, the apparatus includes a $2 \mathrm{~L}$ pear shaped flask filled with water on a hotplate and a 2-L bioflask, which is positioned above. The bioflask contains the fennel herbage. The stillhead is attached to the top of bioflask, and directs the steam to the condenser, which allows for the co-distilled steam and oil to simultaneously collect and separate in a collector, analogous to the Florentine vessel in large com- mercial installations.

The DT evaluated in this experiment included eight different times: 1.25, 2.5, 5, 10, 20, 40, 80, and $160 \mathrm{~min}$. All these DT were measured from the beginning of the distillation (the moment the first drop of essential oil was deposited). At the end of the DT, the power was turned off, the still head was removed, and the oil was separated from the water. The resulting essential oils were measured on an analytical scale, and kept at $-5^{\circ} \mathrm{C}$ until GC/MS analyses were performed. The essential oil content (yield) was calculated as grams of oil per weight of fresh fennel herbage.

\subsection{Gas chromatography (GC) analysis of the fennel es- sential oil}

All fennel essential oil samples (in three replicates) were analyzed on a Hewlett Packard gas chromatograph 6890 GC with an auto sampler (carrier gas helium, $40 \mathrm{~cm} / \mathrm{sec}$, $11.7 \mathrm{psi}\left(60^{\circ} \mathrm{C}\right), 2.5 \mathrm{ml} / \mathrm{min}$ constant flow rate; injection: split $60: 1,0.5 \mu \mathrm{L}$, injector temperature of $220^{\circ} \mathrm{C}$; oven temperature program: $60^{\circ} \mathrm{C}$ for $1 \mathrm{~min}, 10^{\circ} \mathrm{C} / \mathrm{min}$ to $250^{\circ} \mathrm{C}$ ). The column was HP-INNOWAX (cross-linked PEG; $30 \mathrm{~m} \times 0.32$ $\mathrm{mm} \times 0.5 \mu \mathrm{m}$ ), and the flame ionization detector (FID) temperature was $275^{\circ} \mathrm{C}$.

\subsection{The antioxidative capacity of the essential oil extract}

The antioxidative capacity of the oil extracts was determined by the oxygen radical absorbance capacity (ORAC) method as described previously ${ }^{13,14}$. Briefly, samples of extracted oil were prepared for antioxidant capacity tests by mixing $10 \pm 1 \mathrm{mg}$ oil with $1 \mathrm{~mL}$ of water, acetone (1:1) with $7 \%$ methyl- $\beta$-cyclodextrins (w:v). The test was prepared in a 96 well plate by first transferring $25 \mu \lambda$ of $74 \mathrm{mM}$ phosphate buffer saline ( $\mathrm{pH} 7.4)$ to each well. The test sample $(25 \mathrm{uL}$ ) or Trolox $(25 \mu \lambda)$ (which served as the standard) was added to different wells at concentration of $0.2,0.4$, $3.3,6.5,10,13,25,50 \mu \mathrm{g} / \mathrm{ml})$ followed by $150 \mu \mathrm{L}$ of fluorescein $\left(8.16 \times 10^{-5} \mathrm{mM}\right)$. The samples were incubated at 37 ${ }^{\circ} \mathrm{C}$ for $10 \mathrm{~min}$, with $3 \mathrm{~min}$ intermittent shaking (linear, at medium speed). After incubation, the reaction was activat-

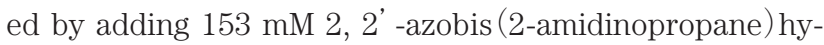
drochloride $(25 \mu \mathrm{L})$, i.e., the radical initiator, to each well. All samples/standards were prepared in 96 well plates and monitored with a BMG Labtech FLUOstar Optima microplate reader (Durham, NC). Fluorescence was measured every $1.5 \mathrm{~min}$ at an excitation and emission wavelength of $485 \mathrm{~nm}$ and $520 \mathrm{~nm}$, respectively, until the decreasing fluorescence values plateaued. From these data, the area under the decay curve was calculated and the results are shown as $\mu$ mole Trolox equivalents/g of extract. Each sample was tested in triplicate.

\subsection{Statistical analyses}

In total, 29 essential oil constituents were identified; of these, 12 constituents with the highest concentration were 
selected for statistical analyses. The effect of distillation time on essential oil content (\%), and the concentrations (\%) and yield (mg) of alpha-phellendrene, trans-anethole, alpha-pinene, beta-pinene, myrcene, paracymene, delta3-carene, cis-ocimene, gamma-terpinene, fenchone, camphor, and cis-anthole was determined using a one-way analysis of variance. For each response, the validity of model assumptions was verified by examining the residuals as described previously ${ }^{15)}$. The effect of distillation time was significant ( $p$-value $<0.05$ ) on essential oil content, all concentrations, and all yields except paracymene and cisanthole. Subsequently, multiple means comparison was completed for all responses significantly affected by distillation time using Duncan's multiple range test at the 5\% level of significance, and letter groupings were generated. The analysis was completed using the GLM Procedure of $\mathrm{SAS}^{16)}$.

Regression analysis to determine the relationship between distillation time and the concentration of each of the constituents suggested that seven of them (essential oil content, and the concentration of paracymene, delta3-carene, gamma-terpinene, fenchone, camphor, and cisanthole) can be adequately modeled using the Power(Eq. 1) model, and three of them (the concentration of trans-anethole, alphaalpha-pinene, and beta-pinene) can be adequately modeled using the second order polynomial (Eq. 2) model. There was no clear relationship between distillation time and the concentration of myrcene and cis-ocimen. The relationship between distillation time and the yields of all ten constituents (alpha-phellendrene, trans-anethole, alpha-pinene, beta-pinene, myrcene, delta-3-carene, cisocimene, gamma-terpinene, fenchone, and camphor)were adequately modeled by the Power (Eq. 1) model. While the Power model is nonlinear, the second order polynomial model is linear. The parameters of the nonlinear model were estimated iteratively using the NLIN Procedure of $\mathrm{SAS}^{16)}$.

$$
\begin{aligned}
& Y=\theta_{1} x^{\theta_{2}}+\varepsilon \\
& Y=\beta_{0}+\beta_{1} x+\beta_{2} x^{2}+\varepsilon
\end{aligned}
$$

Where $Y$ is the dependent (response) variable, $x$ is the independent (distillation time) variable, and the error term $\varepsilon$ is assumed to have normal distribution with constant variance.

\section{RESULTS}

The following constituents were identified in fennel oil: alpha-thujene, alpha-pinene, camphene, sabinene, beta-pinene, myrcene, alpha-phellendrene, alpha-terpinene, paracymene, delta-3-carene, cis-ocimene, gamma-terpinene, fenchone, linalool, trans-pinene hydrate, camphor, transverbenol, 4-terpineol, estragole, fenchyl acetate, cis-anethole, anisaldehyde-para, dimethyl acetal, trans-anethole, para-anisyl methyl Ketone, germacrene-D, trans-methylisoeugenol, delta-cadinene, and 1-(4-methoxy phenyl) -1-propanone. Of these, only the constituents with concentrations greater than $1 \%$ of the oil were statistically analyzed.

Fennel essential oil content increased with increase of DT and reached a maximum of $0.68 \%$ at $160 \mathrm{~min}$ DT (Table 1, Fig. 1). The concentration of alpha-phelandrene (0.9$10.5 \%$ concentration range in the oil) was the lowest at 1.25 min DT and higher at 10, 80, and 160 min DT. The concentration of the main constituent trans-anethole (32.6 - 59.4\% range) was low at 1.25 min DT, generally increased with an increase of the DT at 40-160 min DT. The concentrations of alpha-pinene (7.1-12.4\% of the oil) and beta pinene (0.95-1.64\% range) were higher in the shortest DT and the lowest at $80 \mathrm{~min}$ DT. However, the concentrations of both constituents at 160 min DT were not different from their respective concentrations at 1.25 or 2.5 min DT. The

Table 1 Mean essential oil (EO) content (\%), and the concentrations (\%) of alpha-phellendrene, trans-anethole, alpha-pinene, beta-pinene, myrcene, and paracymene obtained from the 8 distillation times (DT).

\begin{tabular}{cccccccc}
\hline DT (min) & EO content & $\begin{array}{c}\text { Alpha- } \\
\text { phellendrene }\end{array}$ & Trans-anethole & alpha-pinene & beta-pinene & myrcene & paracymene \\
\hline 1.25 & $0.06 \mathrm{f}$ & $0.90 \mathrm{~b}$ & $32.58 \mathrm{~d}$ & $11.8 \mathrm{ab}$ & $1.50 \mathrm{ab}$ & $0.93 \mathrm{c}$ & $5.97 \mathrm{a}$ \\
2.5 & $0.11 \mathrm{ef}$ & $7.58 \mathrm{ab}$ & $39.25 \mathrm{~cd}$ & $12.4 \mathrm{a}$ & $1.64 \mathrm{a}$ & $1.65 \mathrm{ab}$ & $4.67 \mathrm{ab}$ \\
5 & $0.14 \mathrm{e}$ & $5.01 \mathrm{ab}$ & $42.15 \mathrm{~cd}$ & $10.3 \mathrm{abc}$ & $1.37 \mathrm{abc}$ & $1.31 \mathrm{bc}$ & $3.27 \mathrm{abc}$ \\
10 & $0.25 \mathrm{~d}$ & $10.10 \mathrm{a}$ & $46.51 \mathrm{bc}$ & $8.7 \mathrm{abc}$ & $1.17 \mathrm{bc}$ & $1.44 \mathrm{~b}$ & $1.80 \mathrm{bc}$ \\
20 & $0.29 \mathrm{~d}$ & $4.71 \mathrm{ab}$ & $50.30 \mathrm{abc}$ & $8.4 \mathrm{bc}$ & $1.19 \mathrm{abc}$ & $1.21 \mathrm{bc}$ & $3.42 \mathrm{abc}$ \\
40 & $0.40 \mathrm{c}$ & $7.70 \mathrm{ab}$ & $55.03 \mathrm{ab}$ & $8.2 \mathrm{bc}$ & $1.17 \mathrm{bc}$ & $1.38 \mathrm{~b}$ & $2.20 \mathrm{bc}$ \\
80 & $0.52 \mathrm{~b}$ & $10.49 \mathrm{a}$ & $59.39 \mathrm{a}$ & $7.1 \mathrm{c}$ & $0.95 \mathrm{c}$ & $1.57 \mathrm{ab}$ & $1.02 \mathrm{c}$ \\
160 & $0.68 \mathrm{a}$ & $10.03 \mathrm{a}$ & $52.69 \mathrm{ab}$ & $11.9 \mathrm{ab}$ & $1.42 \mathrm{ab}$ & $1.95 \mathrm{a}$ & $0.68 \mathrm{c}$ \\
\hline
\end{tabular}

Within each column, means sharing the same letter are not significantly different at the $5 \%$ level. 

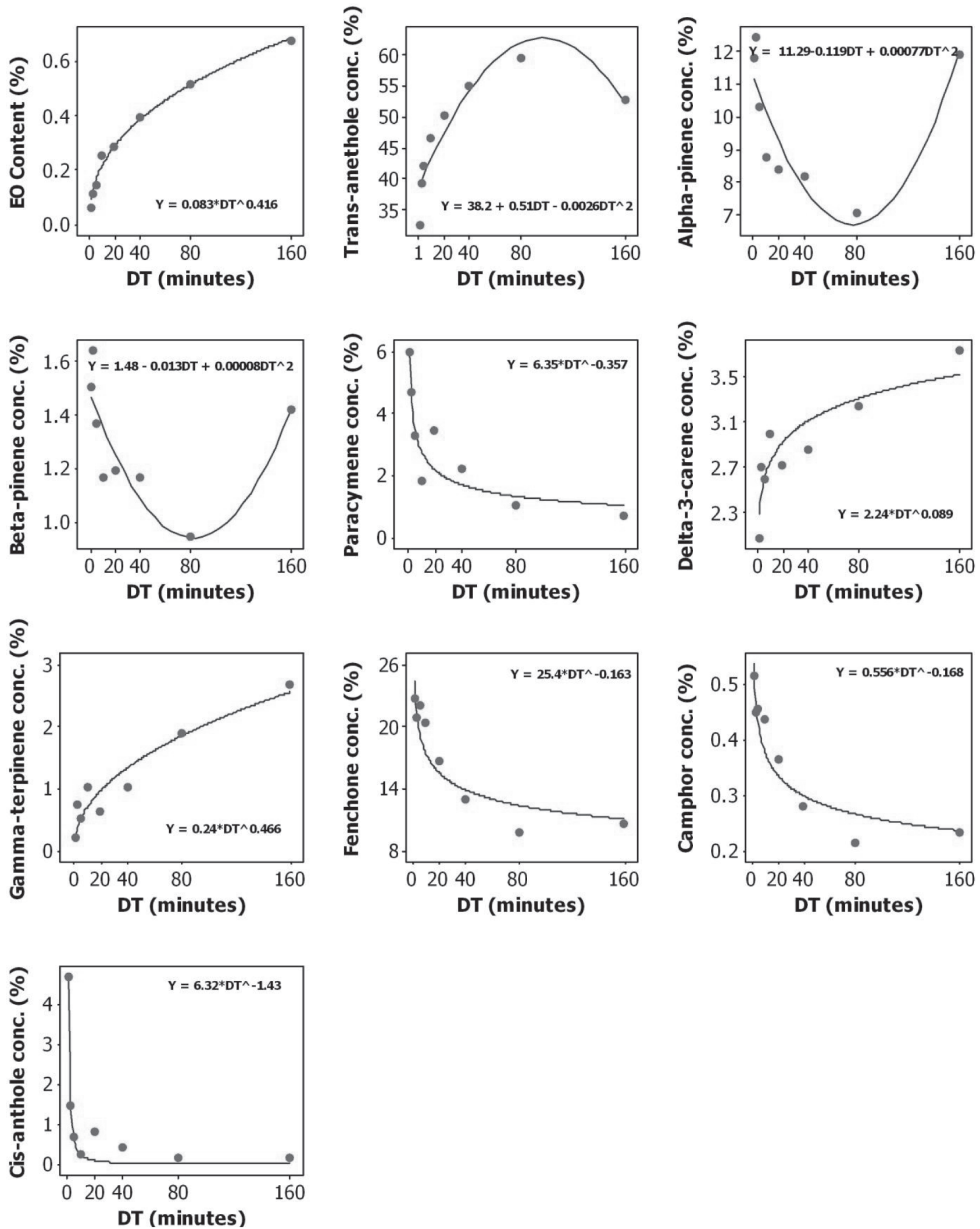

Fig. 1 Plot of Distillation time (DT) vs. Essential oil content, and the concentration of 9 constituents along with the fitted Power and second-order polynomial regression models. Equations of the fitted models are shown within each plot. 
Table 2 Mean concentrations (\%) of delta-3-carene, cis-ocimene, gamma-terpinene, fenchone, camphor, and cis-anthole obtained from the 8 distillation times (DT).

\begin{tabular}{ccccccc}
\hline DT (min) & delta-3-carene & cis-ocimene & gamma-terpinene & fenchone & camphor & cis-anthole \\
\hline 1.25 & $2.08 \mathrm{c}$ & $*$ & $0.22 \mathrm{c}$ & $22.7 \mathrm{a}$ & $0.51 \mathrm{a}$ & $4.66 \mathrm{a}$ \\
2.5 & $2.71 \mathrm{bc}$ & $0.14 \mathrm{~b}$ & $0.75 \mathrm{c}$ & $20.8 \mathrm{ab}$ & $0.45 \mathrm{ab}$ & $1.46 \mathrm{ab}$ \\
5 & $2.60 \mathrm{bc}$ & $0.12 \mathrm{~b}$ & $0.53 \mathrm{c}$ & $22.0 \mathrm{ab}$ & $0.46 \mathrm{ab}$ & $0.69 \mathrm{ab}$ \\
10 & $2.99 \mathrm{ab}$ & $0.13 \mathrm{~b}$ & $1.03 \mathrm{bc}$ & $20.3 \mathrm{ab}$ & $0.44 \mathrm{ab}$ & $0.24 \mathrm{~b}$ \\
20 & $2.72 \mathrm{bc}$ & $0.09 \mathrm{~b}$ & $0.64 \mathrm{c}$ & $16.6 \mathrm{bc}$ & $0.36 \mathrm{bc}$ & $0.83 \mathrm{ab}$ \\
40 & $2.85 \mathrm{bc}$ & $0.13 \mathrm{~b}$ & $1.02 \mathrm{c}$ & $12.9 \mathrm{~cd}$ & $0.28 \mathrm{~cd}$ & $0.43 \mathrm{ab}$ \\
80 & $3.23 \mathrm{ab}$ & $0.15 \mathrm{~b}$ & $1.89 \mathrm{ab}$ & $9.8 \mathrm{~d}$ & $0.21 \mathrm{~d}$ & $0.17 \mathrm{~b}$ \\
160 & $3.72 \mathrm{a}$ & $0.23 \mathrm{a}$ & $2.67 \mathrm{a}$ & $10.6 \mathrm{~d}$ & $0.23 \mathrm{~d}$ & $0.14 \mathrm{~b}$ \\
\hline
\end{tabular}

Within each column, means sharing the same letter are not significantly different at the $5 \%$ level.

Table 3 Mean yield (mg) of alpha-phellendrene, trans-anethole, alpha-pinene, beta-pinene, myrcene, delta-3-carene, cis-ocimene, gamma-terpinene, fenchone, and camphor obtained from the 8 distillation times (DT). The effect of DT on the yields of paracymene and cis-anthole was not significant (p-values 0.227 and 0.771 respectively), and their overall means were $5.87 \mathrm{mg}$ and $2.19 \mathrm{mg}$ respectively.

\begin{tabular}{|c|c|c|c|c|c|c|c|c|c|c|}
\hline DT (min) & $\begin{array}{c}\text { Alpha- } \\
\text { phellendrene }\end{array}$ & $\begin{array}{l}\text { Trans- } \\
\text { anethole }\end{array}$ & $\begin{array}{l}\text { alpha- } \\
\text { pinene }\end{array}$ & $\begin{array}{l}\text { beta- } \\
\text { pinene }\end{array}$ & myrcene & $\begin{array}{l}\text { delta-3- } \\
\text { carene }\end{array}$ & $\begin{array}{c}\text { cis- } \\
\text { ocimene }\end{array}$ & $\begin{array}{l}\text { Gamma- } \\
\text { terpinene }\end{array}$ & fenchone & camphor \\
\hline 1.25 & $0.7 \mathrm{c}$ & $15.62 \mathrm{e}$ & $7.3 \mathrm{~d}$ & $0.93 \mathrm{~d}$ & $0.6 \mathrm{f}$ & $1.3 \mathrm{e}$ & NA & $0.17 \mathrm{~d}$ & $14.1 \mathrm{c}$ & $0.32 \mathrm{c}$ \\
\hline 2.5 & $9.2 \mathrm{c}$ & $35.01 \mathrm{de}$ & $13.7 \mathrm{~cd}$ & $1.81 \mathrm{~cd}$ & 1.4 ef & $3.0 \mathrm{de}$ & $0.16 \mathrm{c}$ & $0.85 \mathrm{~d}$ & $22.9 \mathrm{c}$ & $0.50 \mathrm{bc}$ \\
\hline 5 & $6.9 \mathrm{c}$ & $60.10 \mathrm{~d}$ & $14.7 \mathrm{~cd}$ & $1.96 \mathrm{~cd}$ & $1.9 \mathrm{de}$ & $3.7 \mathrm{~d}$ & $0.16 \mathrm{c}$ & $0.63 \mathrm{~d}$ & $31.5 \mathrm{bc}$ & $0.45 \mathrm{c}$ \\
\hline 10 & $25.5 \mathrm{c}$ & $117.40 \mathrm{c}$ & $21.9 \mathrm{bc}$ & $2.93 \mathrm{bc}$ & $3.6 \mathrm{c}$ & $7.6 \mathrm{c}$ & $0.33 \mathrm{c}$ & $2.60 \mathrm{~cd}$ & $51.2 \mathrm{ab}$ & $1.10 \mathrm{ab}$ \\
\hline 20 & $13.5 \mathrm{c}$ & $146.37 \mathrm{c}$ & $24.2 \mathrm{bc}$ & $3.45 \mathrm{bc}$ & $3.5 \mathrm{~cd}$ & $7.9 \mathrm{c}$ & $0.27 \mathrm{c}$ & $1.76 \mathrm{~cd}$ & $48.4 \mathrm{ab}$ & $1.06 \mathrm{ab}$ \\
\hline 40 & $29.6 \mathrm{bc}$ & $218.49 \mathrm{~b}$ & $31.9 \mathrm{~b}$ & $4.59 \mathrm{~b}$ & $5.5 \mathrm{bc}$ & $11.3 \mathrm{c}$ & $0.50 \mathrm{bc}$ & $3.89 \mathrm{c}$ & $51.3 \mathrm{ab}$ & $1.11 \mathrm{a}$ \\
\hline 80 & $54.5 \mathrm{ab}$ & $306.01 \mathrm{a}$ & $36.1 \mathrm{~b}$ & $4.83 \mathrm{~b}$ & $8.1 \mathrm{~b}$ & $16.7 \mathrm{~b}$ & $0.75 \mathrm{~b}$ & $9.73 \mathrm{~b}$ & $50.5 \mathrm{ab}$ & $1.09 \mathrm{ab}$ \\
\hline 160 & $68.6 \mathrm{a}$ & $325.34 \mathrm{a}$ & $80.8 \mathrm{a}$ & $9.61 \mathrm{a}$ & $13.2 \mathrm{a}$ & $25.2 \mathrm{a}$ & $1.58 \mathrm{a}$ & $17.99 \mathrm{a}$ & $70.8 \mathrm{a}$ & $1.56 \mathrm{a}$ \\
\hline
\end{tabular}

Within each column, means sharing the same letter are not significantly different at the $5 \%$ level.

concentrations of myrcene $(0.93-1.95 \%$ range $)$, delta3 -carene $(2.1-3.7 \%$ range $)$, cis-ocimene $(0-0.23 \%$ range), and gamma-terpinene $(0.22-2.67 \%$ range $)$ were the lowest at $1.25 \mathrm{~min}$ DT and the highest at $160 \mathrm{~min}$ DT.

In contrast, the concentrations of paracymene (0.68$5.97 \%$ range), fenchone (9.8-22.7\% range), camphor (0.21$0.51 \%$ range), and cis-anethole $(0.14-4.66 \%$ range $)$ were highest at shorter DT (1.25-5 min DT) and the lowest at the longest (80-160 min) DT (Table 1, Table 2, Fig. 1).

However, the yield of individual constituents (that was calculated from the essential oil yield and the concentration of the respective constituent in the oil) increased with an increase of DT and reached maximum at 160 min DT (alpha-pinene, beta-pinene, myrcene, delta-3-carene, cisocimene, gamma-terpinene) or at 10-160 min DT (fenchone and camphor) (Table 3, Fig. 2) .

The Power and second order polynomial regression models shown in Fig. 1 and Fig. 2 describe the relationship between DT and the corresponding response variable very well; and the fitted models shown within each plot can be used to predict the values of the response variable at any given DT. While the magnitude and signs of the coefficients for the polynomial model are not physically meaningful, the sign of the second parameter of the Power model (e.g., 0.416 for essential oil content, Fig. 1) indicate whether it is increasing (positive) or decreasing (negative); and its magnitude indicate the rate of increase or decrease.

DT also had an effect on antioxidant capacity of the fennel oil; fennel oils from the 20 and 160 min DT had higher antioxidant capacity than the fennel oil obtained at $1.25 \mathrm{~min}$ DT (Table 4).

\section{DISCUSSION}

The results from this study confirmed the hypothesis that DT has significant effect on fennel essential oil content, composition and antioxidant capacity. Essential oil composition of fennel in this study was similar to previous reports ${ }^{17-24)}$. In particular ${ }^{17)}$, and ${ }^{23)}$ used the same cul- 

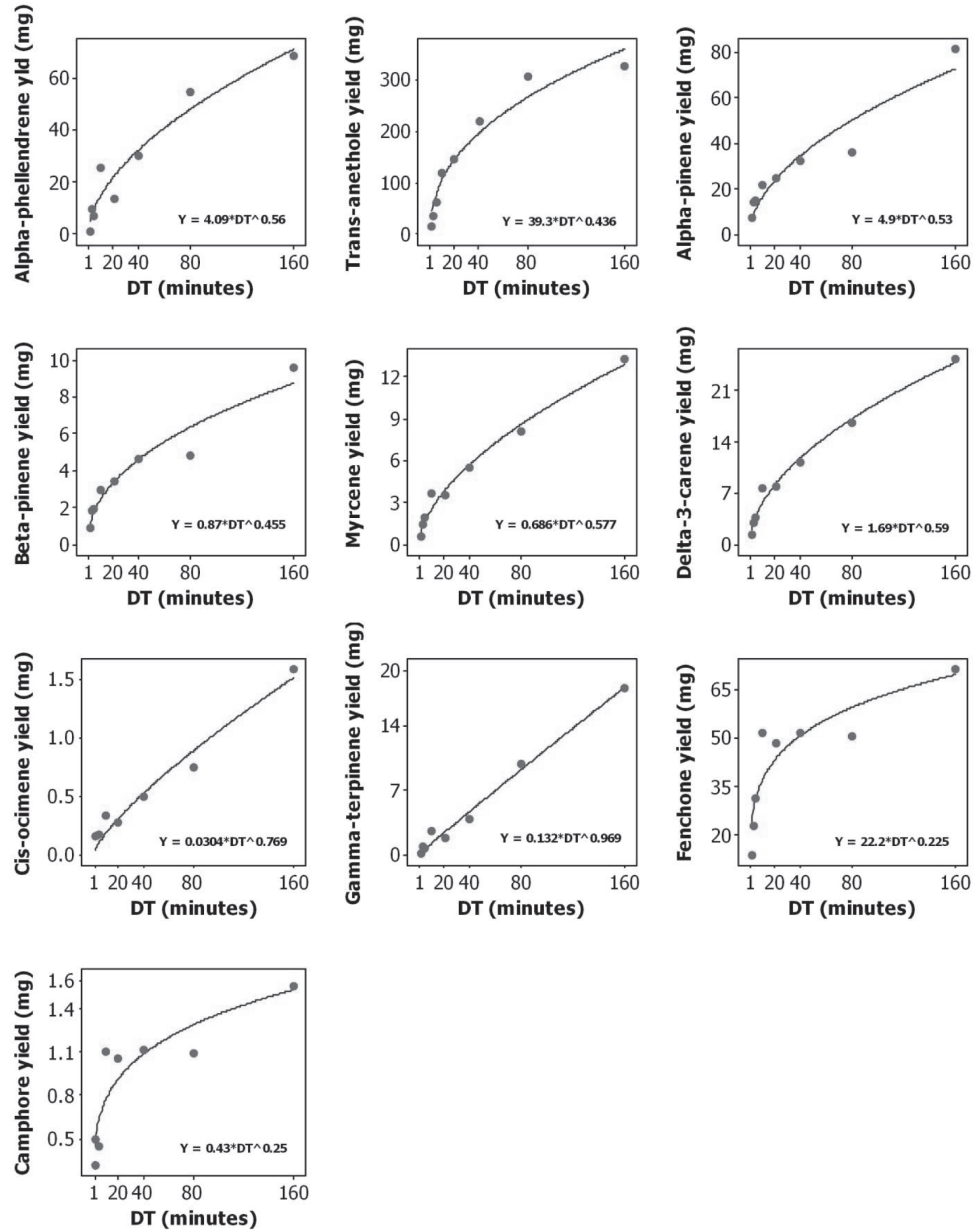

Fig. 2 Plot of Distillation time (DT) vs. the yield (mg) of 10 constituents along with the fitted Power regression model. Equations of the fitted models are shown within each plot. 
Table 4 Antioxidant capacity of fennel oils from $1.25 \mathrm{~min}, 20 \mathrm{~min}$, and $160 \mathrm{~min}$ distillation times (DT).

\begin{tabular}{cc}
\hline DT (min) & Antioxidative capacity $(\mu \mathrm{M}$ Trolox/g) \\
\hline 1.25 & $131 \mathrm{~b}$ \\
20 & $164 \mathrm{a}$ \\
160 & $161 \mathrm{a}$ \\
\hline
\end{tabular}

Means followed by the same letter are not significantly different at the $5 \%$ level.

tivar of fennel as in this study, and reported similar essential oil composition to the one from this study. For example, the main oil constituents in this study were trans-anethole, fenchone, alpha-phellandrene, alpha-pinene, whereas the main constituents in fennel oil in literature report ${ }^{17)}$ were anethole, fenchone, methyl chavicol, alpha-phellandrene, alpha-pinene. Also, anethole concentration in this study varied from 33 to $53 \%$ of the oil, while in literature report ${ }^{17)}$ anethole concentration varied between 40 and $80 \%$ of the oil. On the other hand, literature report ${ }^{21)}$ found $35-82 \%$ anethole concentration range in fennel seed oils obtained from five different countries. However, generally the fennel seed and fennel herb oil may have dissimilar composition.

Fennel essential oil composition depends on various factors among which are genotype ${ }^{18,19,24)}$, cultivar and harvest stage ${ }^{17,25)}$, nitrogen application ${ }^{18)}$, origin ${ }^{21)}$, type of extraction ${ }^{23)}$ to name a few.

According to ${ }^{26)}$, methyl-chavicol in fennel oil should be less than $10 \%$ of the oil and fenchone should be less than $7.5 \%$. The concentration of methyl-chavicol(estragole) in this study was $1.98-2.5 \%$ (data not shown), whereas the concentration of fenchone was $9.8-23 \%$ (Table 1). Longer DT significantly reduced the concentration of fenchone in the oil.

The antioxidative capacity obtained at 20 min DT was significantly higher $(164 \mu \mathrm{M}$ Trolox/g) than that obtained at 1.25 min DT $(131 \mu \mathrm{M}$ Trolox/g). This could be due in part to the substantially lower levels of compounds obtained from the $1.25 \mathrm{~min} \mathrm{DT}(0.06)$ compared to that from the 20 min DT (0.29) and 160 min DT(0.68). Although the total amounts of essential oil contents were different for the 20 min and 160 min DT, the antioxdiatve responses from these distillation times were not significantly different(161-164 $\mu \mathrm{M}$ Trolox/g). The similar levels of alpha-pinene, and betapinene may be acting together in combination, with the main contributor being trans-anethole as this compound is relatively high in both the 20 and 160 DT.

This study demonstrated that DT can significantly alter fennel essential oil composition. Therefore, DT must be taken into consideration when comparing literature report where different distillation times have been used.

\section{CONCLUSIONS}

For high essential oil content, fennel biomass needs to be distilled for $160 \mathrm{~min}$. For high trans-anethole oil, fennel biomass should be distilled for $80 \mathrm{~min}$. For low concentration of fenchone, fennel biomass needs to be distilled for 80-160 min.

DT can be used to obtain fennel essential oil with differential composition. DT can also change the antioxidant capacity of fennel oil. DT must be reported when reporting essential oil content and composition of fennel essential oil. The results from this study will help when comparing reports in which different DT were used to extract essential oil from fennel biomass.

\section{ACKNOWLEDGEMENTS}

This research was funded by ARS Specific Cooperative Agreement 58-6402-4-026 with CRIS MIS-172050 (research grant "Medicinal Herbs Research in Mississippi," awarded to Dr. Jeliazkov[Zheljazkov]).

\section{References}

1) Hay, R. K. M.; Svoboda, K. P. Botany. In: Hay, R. K. M.; Waterman, P.G. (eds) Volatile Oil Crops. Longman Scientific and Technical. P 5-22. Longman House, Burnt Mill, Harlow, Essex, England (1993).

2) Stojanov, N. Astragalus glycyphyllos. In: Ularova, K. (ed) Our medicinal plants. Nauka and Iskustvo, part I, Sofia, pp 165-166 (1972).

3) Albano, S. M.; Miguel, M. G. Biological activities of extracts of plants grown in Portugal. Ind. Crop Prod. 33, 338-343 (2011).

4) Hinneburg, I.; Dorman, H. J. D.; Hiltunen, R. Antioxidant activities of extracts from selected culinary herbs and spices. Food Chem. 97, 122-129 (2006).

5) Choi, E. M.; Hwang, J. K. Antiinflammatory, analgesic and antioxidant activities of the fruit of Foeniculum vulgare. Fitoterapia 75, 557-565(2004).

6) Zheljazkov, V. D.; Astatkie, T. Effect of distillation time on Mentha canadensis essential oil yield and composition. HortScience 47, 643-647 (2012).

7) Zheljazkov, V. D.; Astatkie, T.; Schlegel, V. Distillation time changes oregano essential oil yields and composition but not the antioxidant or antimicrobial activities. HortScience 47, 777-784(2012).

8) Zheljazkov, V. D.; Astatkie, T.; Schlegel, V. Effects of distillation time on the Pinus ponderosa essential oil yield, composition, and antioxidant activity. HortScience 47, 785-789 (2012).

9) Cannon, J. B.; Cantrell, C. L.; Astatkie, T.; Zheljazkov, V. D. Modification of yield and composition of essential 
oils by distillation time. Ind. Crop Prod. 41, 214- 220 (2013).

10) Zheljazkov, V. D.; Astatkie, T.; Jeliazkova, E. A.; Tatman, A. O.; Schlegel, V. Distillation time alters essential oil yield, composition and antioxidant activity of female Juniperus scopulorum trees. J. Essent. Oil Res. 25, 62-69 (2013).

11) Zheljazkov, V. D.; Astatkie, T.; Jeliazkova, E. A.; Schlegel, V. Distillation time alters essential oil yield, composition, and antioxidant activity of male Juniperus scopulorum trees. J. Oleo Sci. 61, 537-546(2012).

12) Zheljazkov, V. D.; Yankuloff, Y.; Raev, R.; Stanev, S.; Margina, A.; Kovatcheva, N. Achievements in breeding on medicinal and aromatic plants in Bulgaria. In: Pank, F. (ed)Breeding Research in Aromatic and Medicinal Plants. Jahrgang, Heft 1, 142-145(1996).

13) Huang, D.; Ou, B.; Hampsch-Woodill, M.; Flanagan, J. Demmer, E. K. Development and validation of oxygen radical absorbance capacity assay for lipophilic antioxidants using randomly methylate B-cylodextrin as the solubility enhancer. J. Agric. Food Chem. 50, 18151821 (2002).

14) Huang, D.; Ou, B.; Hampsch-Woodill, M.; Flanagan, J.; Prior, R. High-throughput assay of oxygen radical absorbance capacity (ORAC) using a multichannel liquid handling system coupled with a microplate fluorescence reader in 96-well format. J. Agric. Food Chem. 50, 4437-4444 (2002).

15) Montgomery, D. C. Design and analysis of experiments. $8^{\text {th }}$ ed. Wiley, New York (2013).

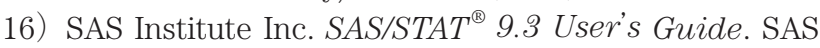
Institute Inc., Cary, NC (2011).

17) Bowes, K.; Zheljazkov, V. D. Essential oil yields and quality of fennel grown in Nova Scotia. HortScience 39, 1640-1643 (2005).
18) Ehsanipour, A.; Razmjoo, J.; Zeinali, H. Effect of nitrogen rates on yield and quality of fennel (Foeniculum vulgare Mill.) accessions. Ind. Crop Prod. 35, 121-125 (2012).

19) Garcia-Jimenez, N.; Perez-Alonso, M. J.; VelascoNegueruela, A. Chemical composition of fennel oil, Foeniculum vulgare Miller, from Spain. J. Essential. Oil Res. 12, 159-162 (2000).

20) Roby, M. H. H.; Sarhan, M. A.; Selim, K. A. H.; Khalel, K. I. Antioxidant and antimicrobial activities of essential oil and extracts of fennel (Foeniculum vulgare L.) and chamomile (Matricaria chamomilla L.). Ind. Crop Prod. 44, 437-445 (2013).

21) Raal, A.; Orav, A.; Arak, E. Essential oil composition of Foeniculum vulgare Mill. fruits from pharmacies in different countries. Nat. Prod. Res. 26, 1173-1178 (2012).

22) Simandi, B.; Deak, A.; Ronyal, E. Supercritical carbon dioxide extraction and fractionation of fennel oil. $J$. Agr. Food Chem. 47, 1635-1640 (1999).

23) Stoyanova, A.; Konakchiev, A.; Kermedchieva, D. Studies on the essential oil of Foeniculum vulgare Mill. var. Dulce Mill. From Bulgaria. Herba Polonica 47, 290-293 (2001).

24) Cavalerio C. M. F.; Rogue, O. L.; Da Cunha, A. P. Contribution for the characterization of Portuguese Fennel Chemotypes. J. Essent. Oil Res. 5, 223-225 (1993).

25) Marotti, M.; Piccaglia, R.; Giovanelli, E. Effects of variety and ontogenetic stage on the essential oil composition and biological activity of fennel(Foeniculum vulgare Mill.). J. Essent. Oil Res. 6, 57-62 (1994).

26) Bilia, A. R.; Flamini, G.; Taglioli, V.; Morelli, I.; Vincieri, F. F. GC-MS analysis of essential oil of some commercial fennel teas. Food Chem. 76, 307-310 (2002). 